\title{
The Integration of Social Skills in Teaching Speaking to Undergraduate English Language Teaching Students
}

\author{
Rusdiah \\ rusdiahandalucia@gmail.com \\ Universitas Sulawesi Barat, Indonesia
}

\begin{abstract}
This study aimed at identifying (1) the social skills and (2) the ways of the lecturer's social skills in teaching speaking. This research employed a descriptive qualitative research design. The instrument of this study involved interview, passive participant observation, and documentation. The subject of this research is the lecturer who teaches speaking and the fourth year students at undergraduate English language teaching students in Universitas Sulawesi Barat. The result of this study showed that there were eighteen social skills that lecturer integrated in teaching speaking both in verbal and nonverbal communication, namely; integrity, diligence, courage, responsibility, religiosity, discipline, creative thinking, curiosity, hard working, self-reliance, problem solving, critical thinking, communication skills, self confidence, decision making, collaborative working/cooperative, respect, and, caring. The ways of lecturer social skills integration in teaching speaking is by verbal and nonverbal communication. In verbal communication are by saying greeting when entering the class, praying before starting and ending the class, taking the register, giving advice to motivate students to study, calling on students by name when talking to them, responding to students reasons for being late, giving feedback to students, asking students to tell their most impressive learning English experience, inserting humor in teaching, telling students his personal experience, allowing students to have individual group consultation, allowing students to call him by his first name, asking students how they feel about their lesson and assignment given, and, using terms like "we" and "us" to refer to the class. Meanwhile, in nonverbal communication are by starting and ending the lesson on time, being enthusiastic in teaching, looking at the class while teaching, looking at the class while teaching, using gesture while talking to the class, using vocal variety, smiling at class while talking, dressing neatly, having a relaxed body posture while talking to the class, having eye contact when calling on a students' name, nodding along students' responses, coming closer to the students when lecturing, walking from back to the front and side-toside between rows when teaching (moving around the class when teaching), looking very little at board or notes while talking to the class, and shaking hands with students.
\end{abstract}

Keywords: social skills, speaking, undergraduate English language teaching students

\section{INTRODUCTION}

For many decades, Indonesia has put high score oriented in learning process (national examination that requires high score). It just involves cognitive aspect (memorizing and drilling) without or very little affective aspect (emotional, social and spiritual). Developing emotional, social and spiritual aspects in our country are, therefore, urgent. 
Social skills are important when interacting with others. That is why poor social skills can influence the biggest factor contributing to success in classroom. Fortunately, social skills can be taught just like academic skills. For example, by integrating social skills in English Language Teaching (ELT) to undergraduate students and it is also recommended by the government.

Moreover, university level that create graduation where English language teacher are being trained/educated should be able to make the undergraduate students prepare hard skills (academic) and soft skills (social skills). As a consequence, everything lecturer does in interacting with the students is possibly followed by students when they are teaching.

In classroom interaction, a lecturer who manages the classroom members by using well performed and appropriate language used whether verbal and nonverbal can see how effective them fostering students positive motivation to learn more. In line with this, Rasyid (2013) described that the main factors which enable the teacher or lecturer to successfully manage and motivate the students to learn depend much upon how the teacher or lecturer manages everyone, including the teacher himself, and everything within the classroom.

By considering some statements above, the researcher was interested to do research study to know social skills that the lecturers integrate in teaching speaking, how social skills are integrated teaching speaking and also to what extent social skills are integrated in teaching speaking. Therefore, the researcher was interested to conduct a research study under the title "The Integration of Social Skills in Teaching Speaking to Undergraduate English Language Teaching Students".

In line background above, the research question was proposed as the following:

(1)What type of social skills are integrated by the ELT lecturer in the teaching of speaking? (2) How does ELT lecturer integrate social skills in instructional activities, especially in the teaching of speaking? Deals with the research question, the objective of this research were to find out social skills are integrated by the lecturers in teaching speaking and the ways of lecturer' social skills integration in the teaching speaking.

\section{LITERATURE OF REVIEW}

\section{Definition of Social Skills}

Elliot et al (1989) defined social skills as learned behaviors that interpersonal relation with peers and adults. They did not consider social skills as global personality traits; rather, these are discrete, situation-specific behaviours that were affected by age, sex, social status, and the personal with which one interacts.

Comb and Slaby in Thorkilddsen (1985) defined social skills as the ability to interact with others in a given social context in specific way that are socially acceptable or value at the same time personality beneficial, manually beneficial, or beneficial primary to others. Social skills are used to interact and communicate with others and done verbally and nonverbally to determine the level of a person's emotional intelligence. 
Social skills deficiencies can be categorized by four basic types, depending upon a child's knowledge of how to perform the behavior in question and the presence or absence or interfering cognitive, emotional, or behavioral responses (Gresham in Elliot et al, 1989)

Pettry (2006) defined social skills are skills that you need when interacting with others. There are certain ways that must behave if people want to have fun and to have others like being around us. For example, people must take turn, share, listen, talk positive about others, be patient, be respectful, and be friendly. Interacting with people who do not use social skills is difficult. You can imagine a person who will not share, gets upset easily and refuses to play by the rules.

Moore (2011) stated that there were a lot of different definitions of social skills, but she thinks of them as the abilities necessary to get along with others and to create and maintain satisfying relationship. In another word, Social skills are about being able to flexibly adjust our behavior to fit s particular situation and our personal needs to desire.

Bremer and Smith (2004) studied about social skills form the basis for social competence. They defined social competence as the degree to which students are able to establish and maintain satisfactory interpersonal relationships, gain peer acceptance, establish and maintain friendships, and terminate negative or pernicious interpersonal relationships.

Schneider in Chi (2008) defined social skills as the ability to implement developmentally appropriate social behaviors that enhance one's interpersonal relationships without causing harm to anyone. Social skills include daily interaction skills such as sharing, taking turns, and allowing others to talk without interrupting. The category of social skills can also be expanded to include facets of self-control such as appropriate anger management. For many children, social skills are learned by observing how others in their environment handle social situation.

Based on the definitions above, the researcher can conclude that social skills are the ability to interact with others that are used in verbal and non verbal communication. Social skills include the ability to communicate, establish relationships with others, respect yourself and others, give and receive criticisms.

At the end, lecturer's social skills integration is the ability of the lecturer to integrate social skills in all kinds of communication behavior whether verbal and nonverbal in teaching context. For verbal communication such as saying greeting when entering the class, giving advice to motivate students to study, and calling on students' by names when talking to them. While nonverbal communication such as eye contact when write attendance list, gestures, body movement, and body positioning.

\section{Classification of Social Skills}

Social skills are a complex concept. Therefore, some experts and institutions have developed their scope and categories. In a word, there are hundreds of important social skills for students to learn. The following are some classification of social skills.

The National Research Council (Lai and Viering, 2012) initiated an investigation into the topic of teaching and assessing $21^{\text {st }}$ century skills, hosting several workshop and seminars beginning in 2005. Out of this work came a framework for categorizing the types of knowledge and skills students need for college and career readiness:

1. Cognitive skills, including critical thinking, non-routine problem solving, and systems thinking. 
2. Interpersonal skills, including complex communication, social skills, teamwork, cultural sensitivity, and dealing with diversity.

3. Intrapersonal skills, including self-management, time management, self development, self-regulation, adaptability, and executive functioning.

Assessment and Teaching of $21^{\text {st }}$ Century Skills (ATC 21) organization has also offered a framework for organizing different types of $21^{\text {st }}$ century skills. This framework includes four classes of skills:

1. Ways of Thinking, which encompasses creativity and innovation; critical thinking, problem solving, and decision-making; and metacognition or learning to learn

2. Ways of Working, which includes communication and collaboration or teamwork

3. Tools for Working, which addresses information literacy and information and communication technology (ICT) literacy

4. Living in the Work, which includes citizenship, life and career skills, and personal and social responsibility

Knoff (2005) in "Stop and Think" program organized social skills into four areas:

1. Survival skills (e.g., listening, following directions, ignoring distractions, using nice or brave talk, rewarding yourself)

2. Interpersonal skills (e.g., sharing, asking for permission, joining an activity, waiting your turn)

3. Problem-solving skills (e.g., asking for help, apologizing, accepting consequences, deciding what to do)

4. Conflict resolution skills (e.g., dealing with teasing, losing accusations, being left out, peer pressure)

Another example is in USA with Character Counts. It formulated character program from Elementary School to University. Its mission is to grow up the fourth " $\mathrm{H}$ " in character education. They are heart, head, hand (skills), and health. Some values in Six Pillars of Character Education namely: Trustworthy, Respect, Responsibility, Fairness, Caring, and Citizenship (Samani, 2014).

Mannix (2002) selected as representative of good character into three basic categories:

1. Characteristics that shows respect for yourself (honesty, integrity, humility, responsibility, effort, and pride)

2. Characteristics that shows respect for others (peace-seeking, generosity, compassion, forgiving, understanding, and loyalty)

3. Characteristics that convey a positive outlook on life (sense of humour, fairness, openmindedness, initiative, optimism, risk-taking)

Lickona in Samani (2014) stated that the important of character education. And he suggested as follows:

1. There is a clear and urgent need.

2. Transmitting values is and always has been the work of civilization.

3. The school's role as moral educator becomes more vital at a time when millions of children get little moral teaching from their parents and when value-centred influence such as church or temple are also absent from their lives.

4. There is a common ethical ground even in our values-conflicted society.

5. Democracies have a special need for moral education.

6 . There is no such thing as value-free education 
7. Moral questions are among the great question facing both the individuals and human race

8. There is broad-based, growing support for values education in the school

Based on the classification of social skills above, the researcher divides in two types of social skills in the classroom. Those are verbal and nonverbal communication that is used to interact with students. According to Khan, there are 35\% verbal communication and $65 \%$ nonverbal communication in daily life. Another expert, Peter F. Drucker states that the most important thing in communication is to hear what is not being said. In addition, action speaks louder than word.

1. Verbal communication

Teaching and learning process is one of communication in the classroom. Verbal communication between lecturer and students can be categorized from how to produce sentences, clause, phrase, and word when someone speaks. During their communication, the lecturer has to perform instructional talk and managerial talk.

Khan (n.d, in Wello, 2013) ${ }^{1}$ in his slide presentation stated that verbal communication means communication with words, written or spoken language. He also divided in two types, namely visual and oral. It consists of listening, speaking, writing, and reading.

Rasyid (2013) defined verbal communication in teaching context referring to stylistic verbal expression in delivering messages of knowledge, skills and attitudes to students (such as saying greeting when entering the class, taking the register, giving advice to motivate students to study, calling on students' by names when talking to them and giving feedback to students).

2. Nonverbal communication

Nonverbal communication which refers to implicit message which are mediated by teacher' actions such as eye contact, gestures, facial expression, body positioning, physical proximity, personal touch, and body movement (Rasyid, 2013).

According to Andersen and Andersen (2005), the majority of communication behaviour that creates close teacher-students relationships appeared to be nonverbal. Individual utilizing nonverbal communication employ a multitude of communicative channels, including proxemic, haptic, oculesic, kinesic, vocalic, and chronemic message. Example of these nonverbal channels can be exemplified through nonverbal communication such as open and forward facing body positions, expressive gesturing, eye contact, vocal variety, smiling, and frequent interactions (Mehrabian, 1971). In theory. These behaviours help students focus on the teachers and lecturers nonverbal message by eliciting arousal in the students, which in turn increases affective and cognitive learning, motivation and compliance.

Mehrabian (1981) noted the impact of communication across the three forms as verbal $7 \%$, vocal $38 \%$ (tone of voice, inflection), and visual 55\% (nonverbal physical behaviors). The visual is the most controllable and perhaps the most unconscious element of the message from sender and receiver. Majority opinion is that these do have similar meanings world-wide with respect to smiling, crying, or showing anger, sorrow, or disgust. However, the intensity varies from culture to culture. 


\section{Speaking}

Speaking is one of the oral skills that play a very essential role in human interaction and communication. In expressing our ideas, minds, and feeling, of course we need to speak. It is the most essential way in which the speaker can express himself through a language learning to speak involves developing a number of complex skills and different types of knowledge about when and how to communicate (Burns and Joyce, 1997: 2).

Stovall (1998: 13) states that speaking is considered as crucial participative of the language students. It requires students to realize that ability to speak a language as the product of language students must be mastered by them. Shumin (1997: 115) states that: "speaking is foreign language is not easy for EFL students because effective oral communication requires the ability how to use the language appropriately in social interaction.

Clark in Lamo (2004) stated that speaking is fundamentally instrument act. Speakers talk in order to have some effects on their listeners. They assert things to change their state of knowledge. They ask them questions to get them to provide information. They request thing to get them to do thing for them.

Based on the definition above, speaking is a mean of oral communication that gives information between speaker who gives information and listener who receive information. In other word, the oral communication involves productive and receptive skills.

\section{METHOD}

\section{Design and Samples}

This research applied qualitative descriptive method to investigate the research questions related to this research. According to Sanjaya (2013), the aim of qualitative descriptive is to describe a clear and deep about social reality and various phenomenon's which are happened in society as a subject research, so it is described feature, characteristic, and model of phenomenon. Gay, et al (2006) stated that qualitative research is the collection, analysis, and interpretation of comprehensive narrative and visual data in order to gain insights into a particular phenomenon and interest. The purpose of qualitative research is to promote deep and holistic or complex understanding of particular phenomenon (an environment, a process or even belief). Descriptive data is usually collected by questionnaire surveys, telephone surveys, interviews, and observation.

This research method is employed to describe social skills that are integrated in teaching speaking skill.

\section{Instrument and Procedure}

There are four kinds of instrument that the researcher employed to obtain the data related to this research. They are passive participant observation, interview, field notes, and documentation. In the first meeting, the lecturer was informed that the study was to find out the social skills and their ways to integrate in teaching speaking. During the observation, the researcher was as an external observer in which she did not directly involve in the situation being observed. 
In addition, the researcher checked all of aspects related to the research by using checklist guide. The observation checklist was adapted from Rasyid (2013) that consisted of 14 item of Verbal Interpersonal Communication Measurement (VICM), and 14 item of non verbal Interpersonal Communication Measurement (NVICM) with in Indonesian version. The recording equipment was used to collect the data during the observation. The total numbers of meetings were three meetings. But according to one expert in Munawir (2011), in qualitative research, the researcher should observe in the field before doing the real research in order to know what aspects that can be researched in the real research. Thus, the total number for each class informally is four meetings.

In order to get the valid data, the researcher did the triangulation process which is the technique of clearance of data validity that employs the other data. In this phase, the researcher cross-checked the interview results with the observation results. The next way in going over the data validity is by using extended fieldwork strategy as Johnson \& Christensen $(2008$, p. 276) implied that 'for both discovery and validation researchers should collect data in the field over an extended time period'.

In qualitative approach, the data collecting is done in natural setting. In order to get the data in natural setting, the researcher is at the location during investigation and start to take data through the recording of the activity of the investigation. Observation as a method provided the researcher with an opportunity to watch the behavioral patterns of the participants during teaching productive skills. The observations are naturalistic because the researcher carries them out.

\section{Data Analysis}

After collecting the data from the observation, interviews, field note, and documentation, it was analyzed with qualitative data analysis.

In general, qualitative researcher in many data analysis using analytical model proposed by Miles and Huberman (1994) are often referred to as interactive data analysis methods. They revealed that the activities carried out in the analysis of qualitative data in an interactive and take place continuously until complete, so the data is already saturated. There are three activities in analyzing the qualitative data, such as: the stage data reduction, data display, and conclusions or verification.

\section{RESULT AND DISCUSSIONS}

The findings are answers to the research question put forward in chapter I.

The social skill integrated in teaching speaking varies from one to another resource. The data elicited from the interviews report that there are 12 social skills commonly integrated. Meanwhile, the data from classroom observation 18 social skills potentially develop. Currently, a similar policy is made using a different label, the integration of character education in national curriculum. There are 18 selected characters fall under the four competencies (Kemendiknas, 2010). The researcher adapted and modified. Table 1.1 represents social skills integrated in speaking from classroom observation. 
Table 1.1. Social skills integrated in teaching speaking

\begin{tabular}{|c|c|c|c|c|c|}
\hline \multirow{2}{*}{ No } & \multirow{2}{*}{ Social skills } & \multicolumn{3}{|c|}{ Classroom observation } & \multirow{2}{*}{$\sum$} \\
\hline & & 1 & 2 & 3 & \\
\hline 1 & $\begin{array}{l}\text { Collaborative working/ } \\
\text { Cooperative }\end{array}$ & 8 & 7 & 7 & 22 \\
\hline 2 & Self confidence & 6 & 8 & 6 & 20 \\
\hline 3 & Caring & 5 & 5 & 8 & 18 \\
\hline 4 & Curiosity & 5 & 4 & 6 & 15 \\
\hline 5 & Hard working & 4 & 4 & 5 & 13 \\
\hline 6 & Discipline & 4 & 4 & 4 & 12 \\
\hline 7 & Communication skills & 3 & 5 & 3 & 11 \\
\hline 8 & Creative thinking & 2 & 2 & 5 & 9 \\
\hline 9 & Respect & 4 & 2 & 3 & 9 \\
\hline 10 & Responsibility & 4 & 2 & 1 & 7 \\
\hline 11 & Critical thinking & 2 & 3 & 2 & 7 \\
\hline 12 & Integrity & 3 & 1 & 2 & 6 \\
\hline 13 & Problem solving & 2 & 1 & 3 & 6 \\
\hline 14 & Diligence & 2 & 2 & 2 & 6 \\
\hline 15 & Decision making & 1 & 2 & 1 & 4 \\
\hline 16 & Self-reliance & 2 & 1 & 1 & 4 \\
\hline 17 & Religiosity & 1 & 1 & 1 & 3 \\
\hline 18 & Courage & 2 & - & - & 2 \\
\hline
\end{tabular}

The students in a large group are difficult to see their ability in speaking. However, a lecturer needs to measure their ability. That is why a lecturer can be categorized into individual work and group work. In this case, the lecturer who was interviewed used group work. By implementing group work in the classroom, it can be an effective method to motivate students, encourage active learning, and integrate social skills. For example: 
critical thinking, communication, decision-making, and collaborative working. The transcription of interview about the integration social skills in teaching speaking can be seen in the following interview quotes:

Kaitannya dengan kemampuan sosial siswa yang biasa kita lakukan sebagai seorang guru khususnya saya ini. terutama kemampuan anakanak dalam bekerjasama itu (cooperative) memang ketika kita melihat anak-anak berinteraksi penggunaan nonverbal dalam pembelajaran itu lebih dominan di beberapa siswa ketimbang kemampuan verbalnya sehinggah untuk mengintegrasikan sebuah pembelajaran saya biasa lakukan grup yang tidak terlalu besar. Ini yang saya lakukan maka akan nampak kemampuan verbal siswa yang lebih dominan. Semakin besar grup itu maka semakin kecil peluangnya untuk menggunakan bahasa verbal secara efektif ketimbang yang tidak terlalu besar kira-kira small groupnya. Itu yang biasa saya lakukan, jadi kalau saya membuat grup untuk melihat skill kemampuan sosialnya anak-anak itu lebih ke small grupnya kira-kira cooperative.

Table 1.2. Observation checklist.

\begin{tabular}{|c|c|c|c|c|c|c|}
\hline \multirow{2}{*}{ No } & \multirow{2}{*}{ Verbal Communication } & \multirow{2}{*}{ Social skills } & \multicolumn{3}{|c|}{$\begin{array}{c}\text { Observation } \\
\text { checklist }\end{array}$} & \multirow[b]{2}{*}{$\sum$} \\
\hline & & & 1 & 2 & 3 & \\
\hline 1 & $\begin{array}{l}\text { Using terms like "we" and } \\
\text { "us" to refer to the class }\end{array}$ & Self confidence & 3 & 3 & 3 & 9 \\
\hline 2 & $\begin{array}{l}\text { Calling on students' by } \\
\text { names when talking to } \\
\text { them }\end{array}$ & Respect & 2 & 3 & 4 & 9 \\
\hline 3 & $\begin{array}{l}\text { Telling students his } \\
\text { personal experience }\end{array}$ & Integrity & 2 & 3 & 4 & 9 \\
\hline 4 & $\begin{array}{l}\text { Giving feedback to } \\
\text { students }\end{array}$ & Responsibility & 2 & 2 & 2 & 6 \\
\hline 5 & $\begin{array}{l}\text { Asking students to tell } \\
\text { their most impressive } \\
\text { learning English } \\
\text { experience }\end{array}$ & Integrity & 3 & 2 & 1 & 6 \\
\hline 6 & $\begin{array}{l}\text { Allowing students to call } \\
\text { him by his first name }\end{array}$ & $\begin{array}{l}\text { Communication } \\
\text { skills }\end{array}$ & 2 & 2 & 2 & 6 \\
\hline 7 & $\begin{array}{l}\text { Responding to students } \\
\text { reasons for being late }\end{array}$ & Caring & 3 & 2 & - & 5 \\
\hline
\end{tabular}




\begin{tabular}{|c|c|c|c|c|c|c|}
\hline 8 & $\begin{array}{l}\text { Asking students how they } \\
\text { feel about their lesson and } \\
\text { assignment given }\end{array}$ & Problem solving & 1 & 2 & 1 & 4 \\
\hline 9 & $\begin{array}{l}\text { Allowing student to have } \\
\text { individual and group } \\
\text { consultation }\end{array}$ & Responsibility & 1 & 1 & 2 & 4 \\
\hline 10 & $\begin{array}{l}\text { Praying before starting } \\
\text { and ending the class }\end{array}$ & Religiosity & 1 & 1 & 1 & 3 \\
\hline 11 & $\begin{array}{l}\text { Saying greeting when } \\
\text { entering the class }\end{array}$ & Caring & 1 & 1 & 1 & 3 \\
\hline 12 & Taking the register & Diligence & 1 & 1 & 1 & 3 \\
\hline 13 & $\begin{array}{l}\text { Inserting humour in } \\
\text { teaching }\end{array}$ & Creative thinking & 1 & 1 & 1 & 3 \\
\hline 14 & $\begin{array}{l}\text { Giving advice to motivate } \\
\text { students to study }\end{array}$ & Caring & 2 & - & - & 2 \\
\hline
\end{tabular}

(Adapted and modified from Rasyid, 2013)

[ relation with the students' social ability who we always do as a teacher/lecture specially me. Generally, students have ability in collaborative working/cooperative. When we see the students interact by using nonverbal in learning is dominant toward some students rather than their verbal ability. Therefore, to make integration in teaching, I always divide them in a small group. I always do like this so it will show us the students' verbal ability dominantly. The bigger group work in the classroom, the smaller opportunity for students in verbal communication. It would be better if the group work is smaller. I always do this in the classroom. If I make group work to see students' social skill, it would be better in small group, for example to see their cooperative...]

There were two observation checklists that were used to find the way of social skills integrated, namely verbal and nonverbal communication. The findings were obtained by attending the class and filled the observation checklist. Table below shows the way of social skills were integrated and frequently used by the lecturer in verbal interpersonal communication measure.

The table above shows that the 14 verbal communication to integrate social skills in classroom. And at the third column is the social skill that was integrated by using verbal communication. It means that by using verbal communication, automatically the lecturer integrated social skills in teaching. At the observation checklist column is the total number of observation, each column illustrates social skills that were integrated in the classroom. Meanwhile, the last column is stigma, the total number of social skills that were integrated as long as observation. 
Table 1.3: Table below shows the social skills used by the lecturer in nonverbal interpersonal communication measure. The table shows that there are two lecturers' nonverbal interpersonal communication that are frequently used. It means that by using nonverbal interpersonal communication automatically, the lecturer integrated two social skills in teaching speaking in the classroom.

It is supported from the interview with the lecturer, his opinion that:.."Authentic experience atau personal experience, yang sesuai dengan pengalaman dirinya sendiri maka pendekatannya itu untuk membangun sosial itu saya mengajarkan question and response. Jadi question and response itu ketika dia bercerita tidak dibiarkan saja bercerita tapi ada respon dari teman-temannya sehingga itu terjadi kemampuan sosial dalam tidak sekedar menceritakan selesai...Sehingga skill disana kira-kira bisa kejujuran dan pasti ada kejujuran disana karena dia akan sejujur-jujurnya sesuai dengan pengalamannya kan bisa saja dan itu kita bisa nilai". .

[..." Authentic experience or personal experience, those are appropriate or suitable with personal experience. So make, to build social skills, I integrate or teach question and respond. It means that when the students tell their experiences, the other students give respond or feedback so indirectly, there are social skills interaction, not only tell their experience after that finish. In this case, those are some social skills integration such as: honesty or integrity. In the reason, the students will tell their experience based on real experience. It can be integrated and assessed....]

\begin{tabular}{|c|l|l|c|l|l|c|}
\hline No & NVICM & Social Skills & \multicolumn{2}{|c|}{$\begin{array}{c}\text { Observation } \\
\text { checklist }\end{array}$} & \multirow{2}{*}{$\sum$} \\
\cline { 2 - 6 } & & & $\mathbf{1}$ & $\mathbf{2}$ & \\
\hline 1 & $\begin{array}{l}\text { Smiling at the class while } \\
\text { talking }\end{array}$ & Respect & 4 & 4 & 3 & 11 \\
\hline 2 & $\begin{array}{l}\text { Having eye contact when } \\
\text { calling on a student's name }\end{array}$ & Caring & 3 & 3 & 4 & 10 \\
\hline 3 & $\begin{array}{l}\text { Nodding along students' } \\
\text { responses }\end{array}$ & Creative thinking & 4 & 3 & 2 & 9 \\
\hline 4 & $\begin{array}{l}\text { Using gesture while talking } \\
\text { to the class }\end{array}$ & Self confidence & 2 & 2 & 2 & 6 \\
\hline 5 & $\begin{array}{l}\text { Using vocal variety (non- } \\
\text { monotone) when talking to } \\
\text { the class }\end{array}$ & Self confidence & 2 & 2 & 2 & 6 \\
\hline 6 & $\begin{array}{l}\text { Having a relaxed body } \\
\text { posture while talking to the }\end{array}$ & Self-reliance & 2 & 2 & 2 & 6 \\
\hline
\end{tabular}


ELT Worldwide Vol. 4 No. 1 (2017)

Rusdiah: The Integration of Social Skills in Teaching ...

\begin{tabular}{|c|c|c|c|c|c|c|}
\hline & class & & & & & \\
\hline 7 & $\begin{array}{l}\text { Being enthusiastic in } \\
\text { teaching }\end{array}$ & Self confidence & 2 & 2 & 2 & 6 \\
\hline 8 & $\begin{array}{l}\text { Looking very little at board } \\
\text { or notes while talking to the } \\
\text { class }\end{array}$ & Hard working & 2 & 1 & 2 & 5 \\
\hline 9 & $\begin{array}{l}\text { Looking at the class while } \\
\text { teaching }\end{array}$ & Self confidence & 1 & 1 & 2 & 4 \\
\hline 10 & $\begin{array}{l}\text { Starting and ending the } \\
\text { lesson on time }\end{array}$ & Discipline & 1 & 1 & 1 & 3 \\
\hline 11 & Dressing neatly & Discipline & 1 & 1 & 1 & 3 \\
\hline 12 & $\begin{array}{l}\text { Coming closer to students } \\
\text { when lecturing }\end{array}$ & Decision making & 1 & 1 & 1 & 3 \\
\hline 13 & $\begin{array}{l}\text { Walking from back to the } \\
\text { front and side-to-side } \\
\text { between rows when teaching } \\
\text { (moving around the class } \\
\text { when teaching) }\end{array}$ & Courage & 2 & - & - & 2 \\
\hline 14 & Shaking hands with students & Caring & - & - & - & - \\
\hline
\end{tabular}

(Adapted and modified from Rasyid, 2013)

\section{CONCLUSIONS, IMPLICATION, AND SUGGESTIONS}

The conclusions of this research were based on the interview which was compared with observation, the researcher found that the social skills integrated in teaching speaking are integrity, respect, diligence, courage, responsibility, religiosity, discipline, creative thinking, curiosity, hard working, self-reliance, problem solving, critical thinking, communication skills, collaborative working/cooperative, self confidence, care, decision making.

The lecturer who was teaching of speaking employed different ways to integrate social skills in the teaching of speaking. However, the lecturer integrated them was by developing activities relevant to the social skills being developed. In other words, he integrated them by process. In fact, only a few of them was by content. There were some ways of lecturer' social skills integrated in teaching are through classroom management, course materials, and method of teaching.

There were three lecturer' verbal and two nonverbal communication that were frequently used. Verbal communication, those are calling on students by name when talking to them, telling students his personal experience, and using terms like "we" and "us" to refer to the 
class. Meanwhile, nonverbal communication, those are smiling at the class while talking and having eye contact when calling on a students' name.

Based on the findings above, it was concluded that the lecturer integrated social skills to the students by using both verbal and nonverbal communication. There are some ways of lecturer' social skills integration in teaching speaking namely: the integration through management of classroom, course materials, and teaching method.

In practical term, this study is an input and a resource of information for lecturers, teachers, students, and stakeholders in teaching English as a Foreign Language. On the other hand, this research study is accepted to introduce and inform for the next writer who wants to conduct a research of the social skills in teaching.

As implication of this research are the following:

1. In the teaching of speaking, social skills should be integrated because studying language means studying the culture of the target language. That is why, it is important that the lecturers have a knowledge of culture of English speaking society. And also, for the students when they interact in society specially in speaking English to avoid misunderstanding. The present study has shown that lecturer and students stated that social skills were integrated in every class session and this meant that every single activity the lecturer and the students do during the teaching-learning process.

2. The integration of social skills to undergraduate ELT students in Unsulbar and other higher education institutions are meaningful for character building. As the present study has shown, by using verbal and nonverbal communication, the lecturer integrated social skills in the teaching of speaking. It depends upon the lecturer sensitivity in identifying and developing good characters inherent in the spoken. Therefore, a lecturer should be able to manage the classroom members by using well performed and appropriated language used whether verbal and nonverbal communication. As the consequence of lecturer's social skills integration will effect to students' social skills while in verbal and nonverbal communication. In Bahasa Indonesia, we have some proverbs "kecil terajak-ajak besar terbawa-bawa". And "ala bisa karena biasa". Those are some illustration about the effect of lecturer's social skills integration. Good characters should be implemented in students' minds to be implemented in their real lives. If it can be realized, peace and unity in diversityIndonesia will exist.

In relation to the conclusion above, the researcher puts forwards some suggestions as follows:

For the first conclusion, the researcher gives some suggestion such as:

- The lecturer should more creative in teaching. Using verbal and nonverbal communication in teaching English is very helpful for the students. It should be better if the lecturer does not sacrifice goal of language teaching due to, for example, prioritizing social skills development.

- To the lecturers in the teaching, especially in speaking subject should show the students that good education requires good lecturer. Therefore, lecturers are expected to have communication skills, not only in the classroom but also in the outdoor.

- The lecturer is expected to improve their gestures in teaching because it is very important for several students. 
- The lecturers have to give his smile to students, so the students will more relax in learning.

- The lecturers also have to keep making eye contact to the students so they feel that their lecturer pay attention to them.

- This study can become a guideline for the English lecturer who wants to be a best lecturer in teaching English.

For the second conclusion, the suggestions are:

- The lecturer should creative to manage the class in order to the students potential will be useful.

- It is strongly advisable that the lecturer should create and opportunities to use the language.

- The lecturer should improve their ability in creating a good method, materials and their attitude in performance during the class. In a reason that the students will be a teacher.

- The lecturer needs to consider the use of both positive verbal and nonverbal communication at the same portion during teaching and learning process so that the students could give their positive response to their lecturer.

- To be successful in the teaching of speaking English, applying various materials and method really help the students to get the improvement in their speaking.

- For future resources could look in to the students' perspective for example social skills integration and its effect on students, learning, and behaviour.

\section{REFERENCES}

Andersen, P. A., and Andersen, J. F. 2005. Measurement of Perceived Nonverbal Immediacy. In V. Manusov (Ed.), The Sourcebook of Nonverbal Measures: Going Beyond Words (pp. 13-126) Mahwah, NJ: Erlbaum

Bremer, Christine D, and Smith, John. 2004. Teaching Social Skills. National Center on Secondary Education and Transition, Vol. 3. Issue 5.

Burns, A and Joyce, H. 1997. Focus on Speaking. Sydney: Macquarie University.

Chi, Lau Wing. 2008. Using Singing Games in Music Lessons to Enhance Young Children's Social Skills. The Hong Kong Institute of Education.

Elliot, Stephen N., Sheridan, Susan M., Gresham, Frank M. (1989). Assesing Social Skills Deficits: A Case Study for the Sientist-Practitionaer. Educational Psychology Papers. University of Nebraska-Lincoln. Vol. 6. Number 2.

Gay, L. R, Geoffrey, E. Mills, and Peter, Airasian. 2006. Educational Research: Competencies for Analysis and Applications. New Jersey: Pearson Education, Inc.

Johnson, B. \& Christensen, L. 2008. Educational researcher: Quantitative, qualitative, and mixed approaches. Los Angeles: Sage Publication.

Kemendiknas. 2010. Pengembangan Pendidikan Budaya dan Karakter Bangsa. Pedoman Sekolah. Jakarta. Badan Penelitian dan Pengembangan.

Knoff, Howard M. 2005. The Stop and Think Social Skills Program. USA. Achieve.

Lai, Emily R, \& Viering, Michaela. 2012. Assessing $21^{\text {st }}$ Century Skills: Integrating Research Findings. National Council on Measurement in Education Vancouver, B.C. 
Lamo, Ahmad. 2004. Encouraging Students to Speak English through Seminar for Oral Communication Skill Development. Makassar. Dissertation UNM.

Mannix, Darlene. 2002. Character Building Activities for Kids. Jossey-Bass. USA.

Mehrabian, Albert. 1981. Silent Message: Implicit Communication or Emotions and Attitudes. ( $2^{\text {nd }}$ ed.). Beltmont, CA: Wadsworth. . 1971. Silent Messages. Beltmont, CA: Wadsworht

Miles, M. B and Huberman, A. M. 1994. Qualitative Data Analysis: Expanded Source book $2^{\text {nd }}$ edition. California: Sage Publication.

Moore, Eileen Kennedy. 2011. Psychology Today Looks at Extraverted. Growing Friendship.

Munawir, Ahmad. 2011. The Influence of Teacher Talk toward Students Attitude to Speak English. Unpublished Thesis. Graduate Program. Makassar. UNM.

Pettry, Danny Wayne. 2006. Building Social Skills through Activities. USA. http://www.DannyPettry.Com

Rasyid, Muhammad Amin. 2013. Verbal and Non-Verbal Immediacy in EFL Classroom. A report study conducted in State University of Makassar. Indonesia.

Samani, Muchlas and Hariyanto. 2014. Konsep dan Model Pendidikan Karakter. Bandung. Remaja Rosdakarya.

Sanjaya, Wina. 2013. Penelitian Pendidikan Jenis, Metode, dan Prosedur. Kencana Perdana Media Group. Jakarta

Shumin, Kang. 1997. Factor to Consider Developing of Speaking English. Forum Journal Vol 35 No. 3 Juli-September page 8.

Thorkilddsen, Ron. 1985. Using an Interactive Video Disc Program to Teach Social Skills ti Handicapped Children. American Annals of the Deaf. Vol. 130, Number 5. America.

Wello, Basri. 2013. Research Method Class. A Power Point Presentation in Teaching Methodology Class at Graduate Program. UNM 